\title{
Methodical system of scientific activity of law students in institutions of higher education
}

\author{
Riabovol L.* \\ Volodymyr Vynnychenko Central Ukrainian State Pedagogical University, Kropyvnytskyi, Ukraine
}

Received: 06.07.2019

Accepted: 21.08 .2019

\begin{abstract}
It is established that scientific activity is an integral part of teaching law students in higher education institutions. The aim of the work is to substantiate the methodical system of scientific work of law students and to determine the principles and conditions for its implementation. The corresponding system is presented as a set of the following interconnected and mutually related components: the subject-subject; the target (purpose and tasks obtaining a high level of scientific, professional and general competencies necessary for legal activities, which is reflected in the program results of studies, and motives of the scientific work of law students, where a special role is played by a high positive motivation of scientific activity); content (a systematic set of legal knowledge, which caused the scientific interest of the student-researcher, and creative intellectual and practical skills, skills, ways of creative activity, values and attitudes); organizational (the totality of the forms, methods, means of scientific activity, the use of which ensures the student's mastery of a certain content and the achievement of a specific scientific result as a component of program learning outcomes, namely: working with scientific literature, writing annotations, reviewing, participating in discussions, writing abstracts, scientific articles, course and qualification (bachelor's and master's) works, project implementation and presentation of relevant scientific results, participation in round table meetings, olympiads, competitions in law); control and productive (control measures and program learning outcomes). The organizational and pedagogical conditions for the implementation of this methodical system in the learning process are defined, namely: the creation in higher educational institutions of a common developing atmosphere in which students are motivated to research; students' readiness for scientific activities and the sequence of its implementation; selection of actual problems; attracting students to conduct interdisciplinary research, to use knowledge from various branches of law in the process of substantiating their position. Experimental verification of the effectiveness of this methodical system is promising in the direction of research.
\end{abstract}

Key words: methodical system, scientific activity, students-lawyers, institutions of higher education, competence, programmatic learning outcomes.

\section{Методична система наукової діяльності студентів-правників у закладах вищої освіти}

\section{Рябовол Л.}

Центральноукраїнський державний педагогічний університет імені Володимира Винниченка, Кропивницький, Україна

\begin{abstract}
Анотація. Встановлено, що наукова діяльність - невід'ємний складник навчання студентів-правників у закладах вищої освіти. Мета роботи - обґрунтувати методичну систему наукової діяльності студентівправників та визначити принципи і умови її реалізації. Відповідна система представлена як сукупність наступних взаємопов'язаних і взаємообумовлених компонентів: суб'єкт-суб'єктного; цільового (мета і завдання - здобуття високого рівня наукових, професійних і загальних компетентностей, необхідних для правничої діяльності, що відображається у програмних результатах навчання, а також мотиви наукової діяльності студентів-правників, зокрема висока позитивна мотивація); змістового (систематизована сукупність правових знань, що викликали науковий інтерес студента-дослідника, та творчих інтелектуальних і практичних умінь, навичок, способів творчої діяльності, цінностей і ставлень); організаційно-технологічного (сукупність фрорм, методів, засобів, прийомів наукової діяльності, застосування яких забезпечує засвоєння студентом певного змісту і досягнення конкретного наукового результату як складника програмних результатів навчання, а саме:
\end{abstract}

\footnotetext{
Corresponding Author: Riabovol Liliia Tarasivna. Tel. +38(066)2925487. E-mail: Iryabovol8@gmail.com Volodymyr Vynnychenko Central Ukrainian State Pedagogical University, Shevchenka st., 1, Kropyvnytskyi, Ukraine, 25006.

Відповідальний автор: Рябовол Лілія Тарасівна. Тел. +38(066)2925487. E-mail: Iryabovol8@gmail.com Центральноукраїнський державний педагогічний університет імені Володимира Винниченка, вул. Шевченка, 1, м. Кропивницький, Україна, 25006.
} 
опрацювання наукової літератури, анотування, рецензування наукових праць, участь у дискусіях, написання рефератів, тез доповідей, наукових статей, курсових, кваліфікаційних (бакалаврських та магістерських) робіт, виконання проектів та презентації відповідних наукових результатів, участь у засіданнях круглих столів, олімпіадах, конкурсах з правознавства); контрольно-результативного (контрольні заходи та програмні результати навчання). Визначено, що організаційно-педагогічними умовами впровадження даної методичної системи в освітній процес є: створення у закладі вищої освіти загального розвивального середовища, в якому студенти заохочуються до наукової діяльності; готовність студентів до наукової діяльності, її наступність і послідовність; відбір актуальних проблем і заохочення студентів до проведення міждисциплінарних досліджень, до використання знань з різних галузей права під час аргументації своєї позиції. Перспективним у напрямку дослідження є експериментальна перевірка ефективності запропонованої методичної системи.

Ключові слова: методична система, наукова діяльність, студенти-правники, заклади вищої освіти, компетентності, програмні результати навчання.

\title{
Методическая система научной деятельности студентов-юристов в высших учебных заведениях
}

\section{Рябовол Л.}

Центральноукраинский государственный педагогический университет имени Владимира Винниченко, Кропивницкий, Украина

\begin{abstract}
Аннотация. Установлено, что научная деятельность - неотъемлемая составляющая обучения студентовюристов в высших учебных заведениях. Цель работы - обосновать методическую систему научной деятельности студентов-юристов, определить принципы и условия ее реализации. Данная система представлена как совокупность следующих взаимосвязанных и взаимообусловленных компонентов: субъектсубъектного; целевого (цель и задания - получение высокого уровня научных, профрессиональных и общих компетентностей, необходимых для юридической деятельности, что отображается в программных результатах обучения, а также мотивы научной деятельности студентов-юристов, особенно высокая позитивная мотивация); содержательного (систематизированная совокупность правовых знаний, которые вызвали научный интерес студента-исследователя, и творческих интеллектуальных и практических умений, навыков, способов творческой деятельности, ценностей и отношений); организационно-технологического (совокупность форм, методов, средств, приемов научной деятельности, использование которых обеспечивает усвоение студентом определенного содержания и достижение конкретного научного результата как составляющего программных результатов обучения, а именно: работа с научной литературой, составление аннотаций, рецензирование, участие в дискуссиях, написание рефератов, тезисов докладов, научных статей, курсовых, квалификационных (бакалаврских и магистерских) работ, выполнение проектов и презентация соответствующих научных результатов, участие в заседаниях круглых столов, олимпиадах, конкурсах по правоведению); контрольно-результативного (контроль и программные результаты обучения). Определены организационно-педагогические условия внедрения данной методической системы в процесс обучения, а именно: создание в высших учебных заведениях общей развивающей атмосферы, в которой студенты мотивированы к научной деятельности; готовность студентов к научной деятельности и последовательность ее проведения; отбор актуальных проблем; привлечение студентов к проведению междисциплинарных исследований, к использованию знаний с различных отраслей права в процессе обоснования своей позиции. Перспективным в направлении исследования является экспериментальная проверка эффрективности данной методической системы.

Ключевые слова: методическая система, научная деятельность, студенты-юристы, высшие учебные заведения, компетентности, программные результаты обучения.
\end{abstract}

\section{Bcmyn}

Конституція України проголошує, що кожна людина має право на вільний розвиток своєї особистості (ст. 23), громадянам гарантується свобода наукової творчості (ч. 1 ст. 54) [1]. Обов'язковою та невід'ємною складовою частиною освітнього процесу у закладах вищої освіти $€$ наукова та інноваційна діяльність (ч. 3 ст.17 Закону України «Про освіту») [2]. Більше того, забезпечення органічного поєднання в освітньому процесі освітньої, наукової та інноваційної діяльності - одне 3 основних завдань закладу вищої освіти. Важливо, що суб'єктами наукової та інноваційної діяльності, крім наукових / науково-педагогічних працівників, є також особи, які навчаються у закладах вищої освіти (ст. 26; ч. 2 ст. 65 Закону України «Про вищу освіту») [3], що є правовою основою залучення здобувачів вищої освіти (студентів, курсантів) до наукової діяльності. 
Такий підхід знайшов своє відображення у визначенні мети вищої освіти, яка спрямовує освітній процес на здобуття особою високого рівня наукових та/або творчих мистецьких, професійних і загальних компетентностей, необхідних для діяльності за певною спеціальністю чи в певній галузі знань (ч. 1 ст. 17 Закону України «Про освіту») [2].

Відштовхуючись від даного положення, мета вищої юридичної освіти - здобуття особою високого рівня наукових, професійних і загальних компетентностей, необхідних для діяльності за спеціальністю «Право».

Meта роботи: обґрунтувати методичну систему наукової діяльності студентів-правників, визначити принципи та умови її реалізації.

\section{II Матеріал і методи дослідження}

Нормативним підґрунтям даної методики є положення п. 1 ст. 6 Закону України «Про освіту», згідно з якими, засадами державної політики у сфері освіти і принципами освітньої діяльності є науковий характер і різноманітність освіти, цілісність і наступність системи освіти [2], а також Стандарт вищої освіти першого бакалаврського рівня галузі знань 08 «Право» спеціальність 081 «Право» [4], відповідні Освітні програми підготовки бакалавра і магістра.

Методологічну основу наразі заклали такі підходи:

- системний, який дозволив розглянути наукову діяльність студентів як цілісну сукупність взаємопов'язаних складників;

- студентоцентрований, згідно з яким, у центрі освітнього процесу - студент, на задоволення потреб якого і спрямовується навчання, надаючи змогу вивчати те, що йому потрібно, у такий спосіб, який підходить саме йому, що, як вказує R. Edwards, дозволяє скоротити зайві витрати людського та освітнього ресурсу, оскільки студенту не потрібно вивчати те, що він уже знає, вміє робити, або, що його не цікавить [5, с. 125];

- компетентнісний, який зорієнтовує наукову роботу студентів-правників на розвиток компетентностей, деталізованих у програмних результатах навчання;

- діяльнісний та аксіологічний, згідно з якими, студент - активний суб'єкт наукової діяльності, різні форми і методи якої забезпечують розвиток у нього правничих навичок, цінностей і ставлень, позитивної професійної мотивації.

Принципами наукової діяльності студентів визначено:

- науковість та інноваційність;

- наступність і послідовність;

- поєднання індивідуального й диференційованого підходів;

- диверсифікацію форм і методів наукової діяльності;

- актуальність та міждисциплінарність наукових досліджень.

Для розкриття теми й досягнення мети роботи вивчалася нормативна, філософрська, психологопедагогічна, юридична література. 3 інформацією, отриманою з відповідних джерел, було проведено аналіз, синтез, порівняння, узагальнення, систематизацію, класифікацію. Для опису структури методики наукової діяльності студентів-правників використано системно-структурний аналіз, для розробки й обґрунтування її компонентів - моделювання.

\section{III Результати}

Виходячи з того, що наукова діяльність - невід'ємний складник навчання студентів-правників у закладах вищої освіти, методику їх наукової діяльності побудовано на основі структури системи навчання юридичних дисциплін. У наших попередніх працях [6, с. 380] її обгрунтовано як сукупність таких взаємопов'язаних і взаємообумовлених інваріантних компонентів:

- суб'єкт-суб'єктний, утворюваний шляхом взаємодії основних суб'єктів навчання - студента й викладача;

- цільовий, який спрямовує навчання, відбиває ідеальні уявлення про його бажані результати в конкретних вимірах; 
- змістовий як система знань, умінь, навичок, способів діяльності, цінностей і ставлень, засвоюваних студентом;

- організаційно-технологічний як сукупність методів, прийомів, засобів, форм навчання; контрольно-результативний.

Цільовий компонент методичної системи наукової діяльності студентів-правників інтегрує мету, завдання і мотиви такої діяльності. Якщо мета - це те, до чого прагне особа, чого хоче досягти, то мотив - рушійна сила будь-якої свідомої діяльності. У науковій діяльності студентів переважають пізнавальні мотиви/ інтереси, які стимулюють потребу поглиблювати й розширювати наявні та отримати нові знання й ефективно їх використовувати для вирішення пізнавальних завдань, проблем. Водночас, враховуючи те, що наукова діяльність студентів $€$ елементом їх професійної підготовки, суттєвою наразі $є$ роль і професійних мотивів, зокрема, за умови, що здобувач освіти усвідомлює значення науково-дослідницьких умінь у своїй майбутній професійній діяльності. Важливо, при цьому, що мотивація має бути позитивною, орієнтувати особу на успішну самореалізацію. За Д. Макклелландом [7], прагнення до професійного успіху і загалом, прагнення досягнень, - одна 3 основних мотиваційних потреб особи, працівника.

Висока позитивна мотивація, як свідчать результати психолого-педагогічних досліджень, може навіть компенсувати недостатньо високий рівень розвитку спеціальних здібностей або прогалини у знаннях, уміннях і навичках студента. Саме тому, формування професійних мотивів навчання, стимулювання потреби у набутті професійних знань, умінь і навичок $€$ важливим завданням в освітньому процесі [8, с. 160].

На важливість позитивної мотивації, стимулювання студентів до вдосконалення себе як особистості й фахівця акцентовано у багатьох працях з професійної підготовки юристів. О. Мурзіна вказує на це у контексті дослідження процесу і умов формування професійних ціннісних орієнтацій майбутніх юристів під час їх фрахової підготовки $[9$, с.69-70]. В.Гришко розглядає мотивацію/ вмотивованість до професійного саморозвитку як базову компетентність правознавців, а бажання успіху на сучасному ринку праці - як ключовий мотив професійного саморозвитку майбутніх правників [10, c. 33].

Роль і значення відповідних мотивів полягає ще й у тому, що вони є однією з умов готовності студента до професійно орієнтованої наукової діяльності.

Готовність до дослідницької діяльності, за Б.Баймухамбетовою, це - цілісне особистісне утворення, що відображає результат внутрішнього інтелектуального й особистісного розвитку, охоплює мотиваційно-ціннісне ставлення до дослідницької діяльності, систему методологічних знань і дослідницьких умінь, професійно-значущі особистісні якості, що забезпечують ефрективність дослідницької діяльності $[11$, с. 6]. Викладену позицію поділяє С. Тутарищева і розглядає таку готовність як інтегровану особистісну якість фахівця, його здатність і прагнення ефективно здійснювати наукові дослідження в професійній сфері. Критеріями такої готовності, вважає вчена, є: необхідні обсяг і якість дослідницьких знань; продуктивність і дієвість дослідницьких умінь; стійка домінантність і перспективність пізнавальних інтересів; позитивне емоційне ставлення особистості до науководослідницької діяльності [12, с. 7].

Питання готовності до наукової діяльності як умови ії ефрективності актуалізується на тлі результатів психолого-педагогічних досліджень, які засвідчили, що найбільші труднощі в навчанні у студентів викликає відсутність вмінь раціонально розподіляти час (65,8\% опитаних); відсутність/ недостатність навичок самоосвіти, вмінь самостійно працювати з науковою літературою (у $24,8 \%$ повільний темп сприйняття інфрормації; у 19,8\% - утруднення при орієнтуванні в друкованому матеріалі); нездатність управляти своєю діяльністю [8, с. 170].

Мета наукової діяльності студентів-правників лежить у площині мети вищої юридичної освіти і передбачає здобуття високого рівня наукових, професійних і загальних компетентностей, необхідних для правничої діяльності. Аналіз Стандарту вищої освіти першого бакалаврського рівня галузі знань 08 «Право» спеціальність 081 «Право» [4] та відповідні Освітні програми підготовки бакалавра і магістра дозволив визначити програмні компетентності, у розвитку яких сприяє наукова діяльність студентів. Його результати викладено у таблиці 1. 
Табл. 1. Програмні компетентності, у розвитку яких сприяє наукова діяльність студентів-правників

\begin{tabular}{|c|c|}
\hline Компетентність & Відповідні здатності, знання, вміння, навички, ставлення \\
\hline $\begin{array}{l}\text { Інтегральна } \\
\text { компетентність }\end{array}$ & $\begin{array}{l}\text { - } \text { розв'язувати складні спеціалізовані задачі та практичні проблеми у } \\
\text { галузі права в процесі навчання та/або професійної діяльності, що } \\
\text { передбачає застосування правових доктрин та принципів і } \\
\text { характеризується комплексністю та невизначеністю умов. }\end{array}$ \\
\hline $\begin{array}{l}\text { Загальні } \\
\text { компетентності }\end{array}$ & $\begin{aligned}- & \text { абстрактно, логічно й критично мислити, аналізувати; } \\
- & \text { збирати й аналізувати інфоормацію з національних та міжнародних } \\
& \text { джерел, оцінювати ї̈ достовірність, використовувати сучасні ІКТ і } \\
& \text { бази даних; } \\
\text { - } & \text { проводити дослідження, грамотно й точно формулювати і } \\
& \text { висловлювати свої позиції, належно їх оббрунтовувати, брати участь } \\
& \text { в аргументованій професійній дискусії; } \\
- & \text { вчитися й оволодівати сучасними знаннями. }\end{aligned}$ \\
\hline $\begin{array}{l}\text { Просресійні } \\
\text { компетентності }\end{array}$ & $\begin{array}{ll}\text { - } & \text { застосувати знання у практичній діяльності при моделюванні } \\
& \text { правових ситуацій; } \\
\text { - } & \text { аналізувати правові проблеми та формувати правові позиції, } \\
& \text { застосовувати юридичну аргументацію; } \\
\text { - } & \text { виявляти проблеми правового регулювання і пропонувати способи їх } \\
& \text { вирішення, включаючи подолання юридичної невизначеності; } \\
\text { - } & \text { логічно, критично й системно аналізувати документи, розуміти їх } \\
& \text { правовий характер і значення; } \\
\text { - } & \text { самостійно готувати проекти актів правозастосування; } \\
- & \text { критично й системно аналізувати правові явища, застосовувати } \\
& \text { набуті знання у професійній діяльності. }\end{array}$ \\
\hline
\end{tabular}

Компетентності деталізуються у програмних результатах навчання. Аналіз освітніх програм, проведений для визначення програмних результатів навчання, у досягненні яких сприяє наукова діяльність студентів-правників, дозволив встановити, що остання глибоко інтегрована в освітній процес, наукові знання - у зміст освіти, наукові методи / методи наукового дослідження - у методику навчання юридичних дисциплін, а наукові результати - у програмні результати навчання. Останні викладено у табл. 2.

Змістовий компонент методичної системи наукової діяльності студентів-юристів змодельовано нами як систематизовану сукупність правових знань, визначених програмою конкретної навчальної дисципліни, що викликали науковий інтерес студента-дослідника, а також творчих інтелектуальних і практичних умінь, навичок, способів творчої діяльності, цінностей і ставлень, окреслених програмними результатами навчання.

Організаційно-технологічний компонент у нашій моделі - узгоджена сукупність форм, методів, засобів, прийомів наукової діяльності, творчої, інтелектуальної за своєю суттю, застосування яких забезпечує засвоєння / опрацювання студентом певного змісту й досягнення конкретного наукового результату як складника програмних результатів навчання.

Науковий результат - нове наукове знання, одержане в процесі фундаментальних / прикладних наукових досліджень і зафріксоване на носіях інформації. Формами представлення наукового результату, відповідно до п. 22 ст. 1 Закону «Про наукову і науково-технічну діяльність», є: звіт, опублікована наукова стаття, наукова доповідь, наукове повідомлення, монографія, наукове відкриття, проект нормативно-правового акта, нормативного документа, науково-методичні документи, підготовка яких потребує проведення відповідних наукових досліджень або містить наукову складову тощо [13]. Крім новизни, ознаками наукового результату є: теоретична й практична значущість; вірогідність та обґрунтованість науковими фрактами; верифікованість; обумовленість такою властивістю наукової діяльності, як свобода, плюралізм, що передбачає і дозволяє проведення наукових досліджень, 
виходячи з різних наукових позицій, підходів; обов'язкове представлення у вигляді методологічно обґрунтованої системи знань.

Табл. 2. Програмні результати навчання, досягненню яких сприяє наукова діяльність студентівправників

\begin{tabular}{|c|c|}
\hline $\begin{array}{l}\text { Програмний } \\
\text { результат }\end{array}$ & Відповідні знання, вміння, навички, ставлення \\
\hline $\begin{array}{l}\text { Соціально- } \\
\text { гуманітарна } \\
\text { ерудованість }\end{array}$ & 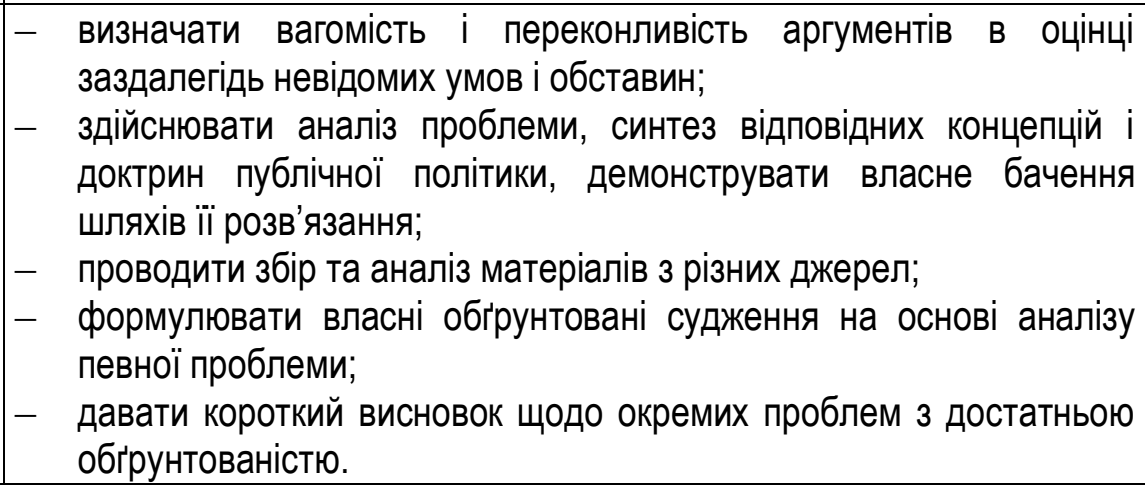 \\
\hline $\begin{array}{l}\text { Дослідницькі } \\
\text { навички }\end{array}$ & $\begin{array}{ll}\text { - } & \text { планувати власне дослідження, формувати матеріали за } \\
& \text { визначеними джерелами; } \\
\text { - } & \text { використовувати різноманітні інформаційні джерела для } \\
& \text { вивчення складних питань з певної теми; } \\
- & \text { визначати й формулювати ті питання, з яких потрібна допомога, } \\
& \text { діяти відповідно до рекомендацій. }\end{array}$ \\
\hline Комунікація & $\begin{array}{l}\text { - } \\
\text { вільно володіти усною і письмовою державною та іноземною } \\
\text { мовами, правильно використовувати правничу термінологію; } \\
\text { - } \\
\text { викладати матеріал } 3 \text { певної проблематики таким чином, щоб } \\
\text { розкрити зміст основних питань; } \\
\text { - відтворювати зміст, демонструючи розуміння основних } \\
\text { професійних та суспільних тем. }\end{array}$ \\
\hline $\begin{array}{l}\text { Професійна } \\
\text { самоорганізація та } \\
\text { використання ІКT }\end{array}$ & 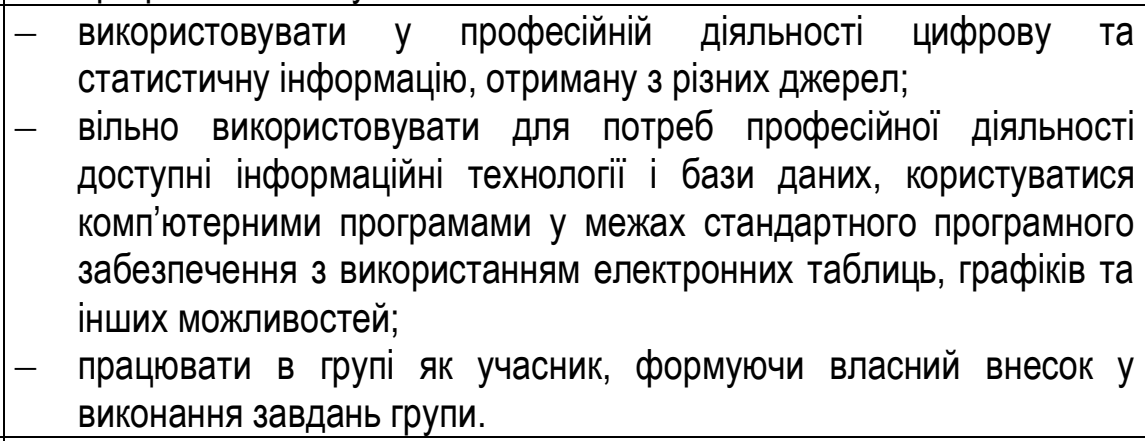 \\
\hline Право-розуміння & $\begin{array}{l}\text { - демонструвати знання і розуміння щодо визначення основних } \\
\text { сучасних правових доктрин, цінностей та принципів } \\
\text { функцціонування національної правової системи; } \\
\text { - пояснювати природу, зміст основних правових інститутів, знати й } \\
\text { розуміти норми та процедури національного права. }\end{array}$ \\
\hline Правозастосування & $\begin{array}{l}\text { - } \\
\text { застосовувати набуті знання у різних правових ситуаціях, } \\
\text { виокремлювати юридично значущі фракти й формувати } \\
\text { обґрунтовані правові висновки; } \\
\text { - самостійно готувати проекти актів застосування права, відповідно } \\
\text { до правового висновку у різних правових ситуаціях; } \\
\text { - надавати консультації щодо можливих способів захисту прав та } \\
\text { інтересів клієнтів у різних правових ситуаціях. }\end{array}$ \\
\hline
\end{tabular}


Для кращого розуміння сутності змістового й діяльнісного компонентів даної методичної системи слід акцентувати, що наукова діяльність настільки глибоко інтегрована в освітній процес, що її важко виокремити «у чистому вигляді». У своїх попередніх працях $[14$, с. 30] ми зазначали, що основою як навчальної, так і наукової діяльності $€$ пізнання - процес цілеспрямованого активного відображення об'єктивного світу в свідомості людей, що відбувається за загальними закономірностями, а саме: рух від незнання до знання, від неповного, поверхового, неточного знання - до більш глибокого, повного, точного. Проте, якщо завдання навчального пізнання - оволодіння вже пізнаними законами навколишнього світу, наприклад, права як об'єктивної реальності, то завдання наукового пізнання відкриття об'єктивно нових знань. Саме тому, наукові дослідження випереджають навчання, відтак, впровадження методів наукового пізнання в освітній процес надають йому випереджального характеру, підвищують його есрективність.

Слід зазначити, що форми і методи наукової діяльності студентів загалом окреслені у відповідних освітніх програмах підготовки правників у закладах вищої освіти. Зокрема, передбачена самостійна робота, виконання індивідуальних завдань, написання курсових і кваліфікаційних робіт. 3 урахуванням цього, а також, виходячи з того, що у рамках освітнього процесу наукову діяльність студенти можуть проводити як під час навчальних занять, так і поза ними, діяльнісний компонент даної методичної системи ми змоделювали як узгоджену сукупність таких форм, методів, прийомів, засобів:

- опрацювання рекомендованої та/або відібраної студентом наукової літератури під час підготовки до семінарських занять та / або самостійної роботи, та використання накопиченого матеріалу під час відповідей (усних та / або письмових);

- анотування та / або рецензування студентом наукових статей, у тому числі іноземною мовою, з відповідним виступом на занятті або без такого;

- впровадження у навчання елементів дискусії, міні-дискусій;

- написання рефератів, тез доповідей з виступом або без такого на науковій (науково-практичній) тематичній та / або звітній конференції;

- написання наукових статей у співавторстві з науковим керівником та опублікування їх у наукових виданнях;

- виконання курсових, кваліфікаційних (бакалаврських та магістерських) робіт;

- виконання інформаційних та/ або дослідницьких проектів і підготовка презентацій для демонстрації відповідних наукових результатів;

- участь студентів у засіданнях круглих столів, олімпіадах, конкурсах з правознавства, зокрема, на кращу студентську наукову роботу / проект.

Відповідними формами представлення наукового результату є: ресрерат, анотація, рецензія, тези доповіді, стаття, курсова робота, кваліфікаційна (бакалаврська, магістерська) робота, презентація, виступ під час навчального заняття, конференції, круглого столу, проект тощо.

Організаційно-педагогічними умовами впровадження даної методичної системи наукової діяльності студентів-правників в освітній процес є:

- створення у закладі вищої освіти загального розвивального середовища, в якому студенти заохочуються до наукової діяльності. Наразі у робочих програмах навчальних дисциплін слід передбачити як види робіт, перелічені вище, так і відповідні бали за їх виконання. В умовах накопичувальної системи оцінювання такий підхід відіграє роль позитивного мотиву як до наукової, так і до навчальної діяльності загалом;

- достатній / високий рівень готовності студентів до наукової діяльності, показниками якої є: позитивна мотивація та наявність знань, умінь і навичок, необхідних і достатніх знань для проведення наукових досліджень, передусім умінь організовувати самостійну діяльність з наукового пошуку. Особливу роль в її забезпеченні відіграють такі навчальні дисципліни - компоненти освітньої програми підготовки бакалавра - «Основи науково-правових досліджень», магістра - «Методологія та організація наукових досліджень»;

- наступність і послідовність наукової діяльності, що передбачає: пізнавальний рух від простого до складного, від відомого до невідомого, від одиничного до загального і навпаки; поступове ускладнення завдань і тематики від року до року навчання, від рівня бакалавра до магістра, урізноманітнюючи форми і методи наукової діяльності та застосовуючи їх, з урахуванням рівня 
готовності студента-дослідника. На дотримання цієї умови доцільно, аби кваліфікаційна робота стала логічним продовженням курсової, що сприятиме грунтовності й глибині студентських наукових робіт;

- відбір актуальних проблем і заохочення студентів до проведення міждисциплінарних досліджень, до використання знань з різних навчальних дисциплін / галузей права під час аргументації своєї позиції. У студентських наукових дослідженнях такий підхід слід реалізувати з огляду на те, що він забезпечує формуванню у студентів єдиної наукової картини світу.

\section{IV Обговорення}

Проблематика наукової діяльності студентів, зокрема здобувачів вищої юридичної освіти, викликає науковий інтерес зарубіжних та вітчизняних фахівців, думки яких багато у чому поділяємо й ми. Так, M. Amador, JE. Fernández-Britto, S. Valido, M. Реп̃a вважають, що наукова діяльність формує у студентів настанови до систематичного набуття й оновлення знань, а робота студентів у наукових робочих групах, тематично пов'язаних з дослідницькими проектами викладачів, у наукових гуртках й оприлюднення відповідних наукових здобутків суттєво підвищує результативність навчання й повинна широко впроваджуватися в навчальний процес [15, с. 345]. Згідно 3 теорією Robert J. Sternberg, рушійною силою наукової діяльності є творчість, креативність, що вимагає поєднання інтелектуальних здібностей, знань, стилів мислення особистості, відповідної мотивації та середовища [16]. R. Shaheen вважає, що впровадження творчості в освітній процес $є$ умовою підвищення ефективності у виконанні завдань освіти, покладених на неї суспільством. Саме наукова діяльність наразі стимулює у здобувачів освіти інтерес до навколишнього світу і прагнення його пізнати, активізує навчально-пізнавальну діяльність $[17$, с. 168]. Доцільність і необхідність проведення студентами-правниками наукової діяльності П. Пономарчук обґрунтовує тим, що дослідження - складова частина усіх видів професійної юридичної діяльності, а вміння їх проводити - особливо важливі для юриста в сучасних умовах правових реформ, оновлення законодавства, виникнення нових сфер юридичної діяльності $[18$, с. 97].

Не можна не погодитися з Ю. Лавриш, що наукова робота студентів, сутність якої вчена вбачає у пошуковій діяльності як самостійному творчому дослідженні, є чинником удосконалення змісту і форм підготовки фахівців у закладах вищої освіти [19]. Роль і значення наукової роботи студентів-юристів для їх подальшої професійної діяльності Н. Пильгун вбачає у тому, що вона сприяє розвитку аналітичного мислення, необхідного для вирішення юридичних справ, здатності до аналітичної оцінки ситуацій [20, с. 128]. Науково-дослідна робота студентів, встановила О. Федорчук, не лише відіграє важливу роль в оволодінні способами здобуття нових знань і формуванні умінь працювати з інформацією, мислити самостійно, критично, творчо, але й сприяє зростанню ваги навчально-пізнавальних і зменшенню ваги меркантильних мотивів студентів під час навчання [21, с. 18]. О. Мурзіна розглядає участь студентів у науково-дослідній роботі, конкурсах, олімпіадах з правових дисциплін, гуртках, конференціях як складник системи формування професійних ціннісних орієнтацій майбутніх юристів [9, с. 140]. 3а В. Савіщенко, самостійна, індивідуально-дослідницька робота студентів-правників - елемент системи формування просресійно значущих якостей майбутнього юриста [22, с. 16].

Результати і висновки перелічених вище та інших дослідників дають підстави стверджувати, що наукова діяльність студентів-правників - інваріантна складова освітнього процесу у закладах вищої освіти і відіграє особливу роль у підготовці до профресійної юридичної діяльності. Разом з тим, у доступних нам працях не запропоновано узагальнену методику організації та проведення наукової діяльності студентів-правників. Саме тому, розробка відповідної методичної системи та обґрунтування умов її впровадження в освітній процес видається нам актуальним і доцільним дослідженням.

\section{V Висновки}

Наукова діяльність - невід'ємний складник навчання студентів-правників у закладах вищої освіти.

Методична система наукової діяльності представлена як сукупність наступних взаємопов'язаних і взаємообумовлених компонентів: суб'єкт-суб'єктного, цільового, змістового, організаційнотехнологічного, контрольно-результативного. Ї̈̈ цільовий компонент інтегрує мету, завдання і мотиви наукової діяльності студентів-правників, де мета передбачає здобуття високого рівня наукових, професійних і загальних компетентностей, необхідних для правничої діяльності, що знаходить своє 
відображення у програмних результатах навчання. Особливу роль, при цьому, відіграє висока позитивна мотивація.

Змістовий компонент даної методичної системи змодельовано як систематизовану сукупність правових знань, що викликали науковий інтерес студента-дослідника, та творчих інтелектуальних і практичних умінь, навичок, способів творчої діяльності, цінностей і ставлень.

Організаційно-технологічний компонент у нашій моделі - узгоджена сукупність форм, методів, засобів, прийомів наукової діяльності, застосування яких забезпечує засвоєння студентом певного змісту і досягнення конкретного наукового результату як складника програмних результатів навчання, зокрема, це: опрацювання наукової літератури; анотування, рецензування наукових статей; дискусії; написання рефератів, тез доповідей, наукових статей, курсових, кваліфікаційних (бакалаврських та магістерських) робіт; виконання проектів та презентації відповідних наукових результатів; участь у засіданнях круглих столів, олімпіадах, конкурсах з правознавства.

Визначено, що організаційно-педагогічними умовами впровадження даної методичної системи наукової діяльності студентів-правників в освітній процес є: створення у закладі вищої освіти загального розвивального середовища, в якому студенти заохочуються до наукової діяльності; достатній / високий рівень готовності студентів до наукової діяльності; наступність і послідовність наукової діяльності; відбір актуальних проблем і заохочення студентів до проведення міждисциплінарних досліджень, використання знань з різних навчальних дисциплін, галузей права під час аргументації своєї позиції. Перспективним у напрямку дослідження $€$ експериментальна перевірка ефективності запропонованої методичної системи.

\section{Бібліографрічні посилання}

1. Конституція України від 28.06.1996 № 254к/96-BP. URL: http://zakon5.rada.gov.ua/laws/show/254к/96-BP (дата звернення 20.06.2019).

2. Про освіту: Закон України від 05.09.2017 р. №2145-19. URL : http://zakon2.rada.gov.ua/laws/show/2145-19 (дата звернення 20.06.2019).

3. Про вищу освіту : Закон України від 01.07.2014 р. № 1556-VII. URL : http://zakon2.rada.gov.ua/laws/show/1556-18 (дата звернення 20.06.2019).

4. Стандарт вищої освіти України: перший (бакалаврський) рівень вищої освіти, галузь знань 08 «Право», спеціальність 081 «Право» : Затверджено і введено в дію наказом Міністерства освіти і науки України від 12.12.2018 р. № 1379. URL : https://mon.gov.ua/storage/app/media/vishcha-osvita/zatverdzeni\%20standarty/12/21/081-pravo-bakalavr.pdf (дата звернення 20.06.2019).

5. Edwards R. Meeting individual learner needs: power, subject, subjection. / In C. Paechter, M. Preedy, D. Scott, and J. Soler (Eds.). Knowledge, Power and Learning. London: SAGE, 2001. P. 123-145. URL : http://www.uk.sagepub.com/books/Book11013 (дата звернення 20.06.2019).

6. Рябовол Л. Т. Система вищої юридичної освіти в Україні. Часопис Київського університету права. 2016. № 2. С. 379383.

7. McClelland D. The Achieving Society. Academic Press, London and New York, 1952. 410 s.; Макклелланд Д. Мотивация человека [перев. с англ.]. СПб. Питер, 2007. 672 с.

8. Подоляк Л. Г., Юрченко В. І. Психологія вищої школи : Навчальний посібник для магістрантів і аспірантів. К.: ТОВ «Філ-студія», 2006. 320 с.

9. Мурзіна О. А. Формування професійних ціннісних орієнтацій майбутніх юристів у процесі фрахової підготовки: дис. ... канд. пед. наук : 13.00.04. Запоріжжя, 2017. 318 с.

10. Гришко В.І. Формування базових компетентностей майбутніх правознавців у процесі фрахової підготовки: дис. ... канд. пед. наук : 13.00.04. Рівне, 2016. 299 с.

11. Баймухамбетова Б. Ш. Формирование готовности магистрантов к исследовательской деятельности : автореф. дис. на соискание научн. степени канд. пед. наук : 13.00.08. Челябинск, 2011. 20 с.

12. Тутарищева С. М. Формирование готовности будущих специалистов к научно-исследовательской деятельности в профессиональной сфере (на примере специальности - «Юриспруденция») : автореф. дис. на соискание научн. степени канд. пед. наук : 13.00.08. Майкоп, 2006. 20 с.

13. Про наукову i науково-технічну діяльність: Закон України від 26.11.2015 p. № 848-VIII. URL: http://zakon5.rada.gov.ua/laws/show/848-19 (дата звернення 20.06.2019).

14. Рябовол Л. Т. Сутність навчання правознавства як процесу пізнання. Освіта Донбасу: науково-методичне видання. 2011. № 3 (146). C. 27-32.

15. Amador M., Fernández-Britto JE., Valido S., Peña M. The scientific work of students: its role in the formation of health professionals. Educacion Medica Y Salud. 1984. № 8(4). P. 344-358.

16. Sternberg Robert J. The Nature of Creativit. Creativity Research Journal. 2006. Vol. 18. No. 1. P. 87-98.

17. Shaheen R. Creativity and Education. Creative Education. 2010. Vol. 1. No. 3. P. 166-169. DOI: 10.4236/ce.2010.13026 
18. ПономарчукП.Н. Исследовательская компетенция как цель подготовки будущих юристов. Вестник ЮжноУральского государственного университета. Серия «Образование. Педагогические науки». Вып. 13. 2011. № 24. C. $96-100$.

19. Лавриш Ю. Е. Особливості організації науково-дослідницької діяльності студентів вищих навчальних закладів. Вісник Національного технічного університету України «Київський політехнічний інститут». Серія: Філологія. Педагогіка. 2013. Вип. 2. С. 72-76.

20. Пильгун Н. В. Методика підготовки студентів молодших курсів юридичного спрямування до науково-дослідної роботи. Наукові праці Національного авіаційного університету. Серія «Юридичний вісник. Повітряне і космічне право». 2010. № 4(17). С. 124-128.

21. Федорчук О.С. Формування у майбутніх правознавців навичок професійного застосування інформаційнокомунікативних технологій : автореф. дис. ... канд. пед. наук : 13.00.04. Київ, 2008. 22 с.

22. Савіщенко В. М. Педагогічні умови формування професійно значущих якостей майбутнього юриста в навчальновиховному процесі вищого навчального закладу : автореф. дис. на здобуття наук. ступеня канд. пед. наук : 13.00.04. Запоріжжя, 2008. 22 с.

\section{References}

1. Konstytutsiia Ukrainy: Zakon Ukrainy vid 28.06.1996 № 254k/96-VR [The Constitution of Ukraine: Law of Ukraine dated June 28, 1996 No. 254k/96-BP]. URL: http://zakon5.rada.gov.ua/laws/show/254k/96-BP (accessed 20.06.2019). [in Ukrainian].

2. Pro osvitu: Zakon Ukrainy vid 05.09.2017 r. № 2145-19 [On Education: Law of Ukraine dated September 5, 2017 No. 214519]. URL: http://zakon2.rada.gov.ua/laws/show/2145-19 (accessed 20.06.2019). [in Ukrainian].

3. Pro vyshchu osvitu: Zakon Ukrainy vid 01.07.2014 r. № 1556-VII [On Higher Education: Law of Ukraine dated 01.07.2014 No. 1556-VII]. URL: http://zakon2.rada.gov.ua/laws/show/1556-18 (accessed 20.06.2019). [in Ukrainian].

4. Standart vy shhoyi osvity Ukrayiny`: pershy”j (bakalavrs’ky`j) riven` vy’shhoyi osvity”, galuz` znan` 08 «Pravo», special’nist” 081 «Pravo» : Zatverdzheno i vvedeno v diyu nakazom Ministerstva osvity` i nauky` Ukrayiny” dated 12.12.2018 p. No. 1379. URL : $\quad$ https://mon.gov.ua/storage/app/medial vishcha-osvita/zatverdzeni\%20standarty/12/21/081-pravo-bakalavr.pdf (accessed 20.06.2019). [in Ukrainian].

5. Paechter, C., Preedy, M., Scott, D., Soler, J. (Eds.), Edwards R. (2001). Meeting individual learner needs: power, subject, subjection. Knowledge, Power and Learning.. London: SAGE. 123-145. URL : http://www.uk.sagepub.com/books/Book11013 (accessed 20.06.2019).

6. Ryabovol, L.T. (2016). Sy’stema vy`shhoyi yury'dy`chnoyi osvity` v Ukrayini [The system of higher legal education in Ukraine]. Chasopy`s Ky`yivs`kogo universy`tetu prava [Journal of the Kyiv University of Law], 2, 379-383. [in Ukrainian]

7. McClelland, D. (1952). The Achieving Society. Academic Press, London and New York, 410.

8. Podoliak, L.H., Yurchenko, V.I. (2006). Psykholohiia vyshchoi shkoly: Navchalnyi posibnyk dlia mahistrantiv i aspirantiv [Psychology of Higher School: A Manual for Graduate Students and Postgraduate Students]. TOV «Fil-studiia», Kyiv, Ukraine, 320. [in Ukrainian].

9. Murzina, O.A. (2017). Formuvannia profesiinykh tsinnisnykh orientatsii maibutnikh yurystiv u protsesi fakhovoi pidhotovky [Formation of Professional Values Orientations of Future Lawyers in the Process of Professional Training]. Candidate's thesis. Zaporizhzhia, 318. [in Ukrainian].

10. Hryshko, V.I. (2016). Formuvannia bazovykh kompetentnostei maibutnikh pravoznavtsiv u protsesi fakhovoi pidhotovky [Formation of Basic Competences of Future Lawyers in the Process of Professional Training]. Candidate's thesis. Rivne, 299. [in Ukrainian].

11. Baimukhambetova, B.Sh. (2011). Formirovanie gotovnosti magistrantov $k$ issledovatelskoi deiatelnosti [Formation of Readiness of Undergraduates to Research Activities]. Extended abstract of candidate's thesis. Cheliabinsk, 20. [in Russian].

12. Tutarishcheva, S.M. (2006). Formirovanie gotovnosti budushchikh spetsialistov k nauchno-issledovatelskoi deiatelnosti v professionalnoi sfere na primere spetsialnosti IUrisprudentsiia [Formation of the Readiness of Future Specialists to Research Activities in the Professional Sphere (on the Example of the Special Field - "Law")]. Candidate's thesis. Maikop, 20. [in Russian].

13. Pro naukovu i naukovo-tekhnichnu diialnist : Zakon Ukrainy vid 26.11.2015 r. No. 848-VIII [On Scientific and Technical Activities: Law of Ukraine dated November 26, 2015 № 848-VIII]. URL: http://zakon5.rada.gov.ua/laws/show/848-19 (accessed 20.06.2019). [in Ukrainian].

14. Ryabovol, L.T. (2011). Sutnist navchannya pravoznavstva yak procesu piznannya [The essence of teaching law as a process of knowledge]. Osvita Donbasu: naukovo-metody'chne vy'dannya [Donbas Education: scientific and methodical publication], 3 (146), 27-32. [in Ukrainian].

15. Amador, M., Fernández-Britto, J.E., Valido, S., Peña, M. (1984). The scientific work of students: its role in the formation of health professionals. Educacion Medica Y Salud, 8(4), 344-358.

16. Sternberg, Robert J. (2006). The Nature of Creativit. Creativity Research Journal, 18, 1, 87-98.

17. Shaheen, R. (2010). Creativity and Education. Creative Education. 1, 3, 166-169. DOI: 10.4236/ce.2010.13026.

18. Ponomarchuk, P.N. (2011). Issledovatelskaia kompetentsiia kak tsel podgotovki budushchikh iuristov [Research Competence as the Goal of Preparing Future Lawyers]. Vestnik IUzhno-Uralskogo gosudarstvennogo universiteta Seriia Obrazovanie Pedagogicheskie nauki - Bulletin of the South Ural State University. Series "Education. Pedagogical Sciences", 13, 24, 96-100. [in Russian]. 
19. Lavrysh, Yu.E. (2013). Osoblyvosti orhanizatsii naukovo-doslidnytskoi diialnosti studentiv vyshchykh navchalnykh zakladiv [Peculiarities of Organization of Research Activities of Students of Higher Educational Institutions]. Visnyk Natsionalnoho tekhnichnoho universytetu Ukrainy «Kyivskyi politekhnichnyi instytut». Seriia: Filolohiia. Pedahohika - Bulletin of the National Technical University of Ukraine "Kyiv Polytechnic Institute". Series: Philology. Pedagogy, 2, 72-76. [in Ukrainian].

20. Pylhun, N.V. (2010). Metodyka pidhotovky studentiv molodshykh kursiv yurydychnoho spriamuvannia do naukovo-doslidnoi roboty [Methodology of Preparation of Students of Junior Legal Courses for Scientific Research]. Naukovi pratsi Natsionalnoho aviatsinoho universytetu. Seriia «lurydychnyi visnyk. Povitriane i kosmichne pravo» - Scientific Papers of the National Aviation University. Series "Legal Bulletin. Aerospace and Law", 4(17), 124-128. [in Ukrainian].

21. Fedorchuk, O.S. (2008). Formuvannia u maibutnikh pravoznavtsiv navychok profesiinoho zastosuvannia informatsinokomunikatyvnykh tekhnolohii [Formation of Future Jurisprudence Skills of Professional Application of Information and Communication Technologies]. Extended abstract of candidate's thesis. Kyiv, 22. [in Ukrainian].

22. Savishchenko, V.M. (2008). Pedahohichni umovy formuvannia profesiino znachushchykh yakostei maibutnoho yurysta v navchalno-vykhovnomu protsesi vyshchoho navchalnoho zakladu [Pedagogical Conditions for the Formation of Professionally Significant Qualities of the Future Lawyer in the Educational Process of a Higher Educational Establishment]. Candidate's thesis. Zaporizhzhia, 22. [in Ukrainian].

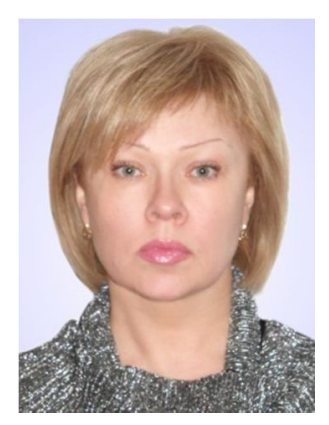

\section{Рябовол Лілія Тарасівна.}

Доктор педагогічних наук, профресор, профресор кафедри державно-правових дисциплін та адміністративного права,

Центральноукраїнський державний педагогічний університет імені Володимира Винниченка, вул. Шевченка, 1, м. Кропивницький, Україна, 25006.

Тел. +38(066)2925487. E-mail: Iryabovol8@gmail.com

\section{Riabovol Liliia Tarasivna.}

Doctor of Pedagogical Sciences, Professor, Professor of State-legal Disciplines and Administrative Law

Department, Volodymyr Vynnychenko Central Ukrainian State Pedagogical University,

Shevchenka st., 1, Kropyvnytskyi, Ukraine, 25006.

Tel. +38(066)2925487. E-mail: Iryabovol8@gmail.com

ORCID: 0000-0003-3558-2103

\section{Citation (APA):}

Riabovol, L. (2019). Methodical system of scientific activity of law students in institutions of higher education. Engineering and Educational Technologies, 7 (3), 10-20. doi: https://doi.org/10.30929/2307-9770.2019.07.03.01

\section{Цитування (ДСТУ 8302:2015):}

Рябовол Л. Методична система наукової діяльності студентів-правників у закладах вищої освіти / Інженерні та освітні технологіiі. 2019. Т. 7. № 3. С. 10-20. doi: https://doi.org/10.30929/2307-9770.2019.07.03.01

Обсяг статті: сторінок-11; умовних друк. аркушів - 1,593. 